\title{
ASSESSMENT OF BIOACTIVE COMPOUNDS IN RED WINES AVAILABLE FOR PURCHASE IN LATVIA
}

\author{
Zane Legzdina” ${ }^{\#}$ Evita Straumīte, and Zanda Krūma \\ Faculty of Food Technology, Latvia University of Life Sciences and Technologies, 22 Rīgas Str., Jelgava, LV-3001, LATVIA \\ \# Corresponding author, legzdina.zane@gmail.com
}

Communicated by Tatjana Ķince

\begin{abstract}
Moderate consumption of wine is associated with positive health effects. Red wine contains more polyphenolic compounds than white wine, so it is considered healthier. The aim of the study was to determine the concentration of bioactive compounds of red grape and berry wines available for purchase in Latvia. A selection of 15 red grape and berry wines purchased in Latvian supermarkets were analysed. The total phenol concentration was determined using the Folin-Ciocalteu spectrophotometric method with minor modifications. Total flavonoid concentration was determined using the colorimetric flavonoid determination method. Antiradical activity was determined using the DPPH (2,2-diphenyl-1-picrylhydraziyl) reagent and ABTS (2,2-azino-bis(3-ethylbenzothiazoline-6-sulfonate) radical cation determination method. The results show that the analysed red wine samples can be divided into five clusters according to the concentration of total phenols, flavonoids, and antiradical activity. Cluster 1 separately divided Latvian black chokeberry wine, with high total phenol concentration (TPC) and total flavonoid concentration (TFC), high antiradical activity via the DPPH method, and relatively low antiradical activity via ABTS method. Cluster 4 combined red wines with medium TPC, high TFC and high antiradical activity via both $D P P H$ and ABTS methods, and included grape wines from different countries of origin. Cluster 5 combined red wines with high TPC, medium TFC, and medium antiradical activity via both DPPH and ABTS methods.
\end{abstract}

Keywords: black currant wine, phenolic compounds, antiradical activity.

\section{INTRODUCTION}

Wine is one of the most widely used alcoholic beverages in the world, especially in European countries and America. In recent years, wine, especially the red wine, is becoming more and more popular because of its sensory properties (taste, aroma) and chemical composition. Wine consumption in a moderate amount can positively influence human health - reduce coronary heart and atherosclerotic diseases risk (Corder et al., 2015). Although excessive alcohol consumption can cause serious health problems, it has been concluded that moderate wine consumption can have the opposite effect by improving health (Bonello et al., 2016). The recommended dose of wine for a healthy adult is $0.4 \mathrm{ml}$ per kilogram of body weight, which is on average one (150 $\mathrm{ml})$ to two $(300 \mathrm{ml})$ glasses of wine per day (Bodnieks et al., 2015). The positive health effects of wine are based on the action of polyphenolic compounds in wine, which are formed during red wine fermentation when grape juice is fermented together with grape skins, grape seeds, and other grape fragments. It has been concluded that red wines contain at least ten times more polyphenolic compounds than white wines, so they are considered healthier. The total polyphenol concentration in red wines ranges from 2000 to $6000 \mathrm{mg} \cdot \mathrm{l}^{-1}$, depending on the variety. These polyphenolic compounds mainly provide the sensory properties (colour, bitter, and astringent taste, and aroma) of red wines but also inhibit the formation of free radicals in the human body and thus reduce the risk of diseases caused by oxidative stress (Bonello et al., 2016; Garavaglia et al., 2016; ChamizoGonzalez et al., 2020).

Traditionally wine is made from white or red wine grapes, but nowadays it is made from non-traditional raw materials as well, such as berries and fruit. Berry and fruit wines are produced in many countries around the world: France, the United States, the United Kingdom, South Korea, and Latvia (Čakar et al., 2016, Giri et al., 2018). The main phenolic 
compounds in chokeberries and black currants are anthocyanins, which give the berries their dark colour. Chokeberries contain cyanidin 3-galactoside, cyanidin 3-arabinoside, cyanidin 3-glycoside, and cyanidin 3-xyloside, as well as flavonols (quercetin 3-glycoside, quercetin 3-galactoside, quercetin 3-rutinoside, quercetin 3-robinobiose and quercetin 3-vicyanoside, kaemferol) and phenolic acids, in particular chlorogenic acid (Sidor and Gramza-Michalowska, 2019). The main phenolic compounds in black currants are delphinidin 3-glycoside, delphinidin 3-rutinoside, cyanidin 3-rutinoside and cyanidin 3-glycoside (Cortez and Gonzalez de Mejia, 2019). Black currant and chokeberry berries are well recognised for their rich chemical composition, but so far the chemical composition and biological activity of black currant and chokeberry wines have been little studied in comparison with foreign grape wines.

Therefore, the aim of the current study was to determine the concentration of bioactive compounds of red grape and berry wines available for purchase in Latvia.

\section{MATERIALS AND METHODS}

Wine samples used in the study. Fifteen red grape and berry wines available for purchase in Latvian supermarkets were analysed in the study (Table 1). The study included local berry (black chokeberry and black currant) red wines as well as foreign red wines from well-known wine producing countries - Spain, France, Italy, Argentina, and Australia. All red wines analysed in the study were chosen according to the principles of accessibility and convenience. The main inclusion criteria were wine colour (only red wines were included in the study) and wine price (5.00 to 15.00 EUR per 0.751 bottle), which are the main wine selection criteria for Latvian consumers (Legzdina and Straumite, 2020).
Determination of total phenol concentration. Total phenol concentration (TPC) of red wine samples was determined using the Folin-Ciocalteu spectrophotometric method (Lamuela-Raventos et al., 1999) with minor modifications. Wine samples were diluted $1: 50$ with distilled water. 0.5 $\mathrm{ml}$ of diluted wine solution was mixed with $2.5 \mathrm{ml}$ of Folin-Ciocalteu reagent, which was diluted $1: 10$ with distilled water. After 5 minutes, $2 \mathrm{ml}$ of $7.5 \% \mathrm{Na}_{2} \mathrm{CO}_{3}$ was added and mixed. Samples were kept at room temperature $\left(22 \pm 1{ }^{\circ} \mathrm{C}\right)$ for $30 \mathrm{~min}$. Absorbance was determined at wavelength $\lambda=765 \mathrm{~nm}$ using a UV-VIS JENWAY 6300 spectrophotometer (Baroworld Scientific Ltd, United Kingdom). Total phenol concentration of the analysed wine samples was expressed as miligrams of gallic acid equivalent per $100 \mathrm{ml}^{-1}$ of wine (GAE mg $\cdot 100 \mathrm{ml}^{-1}$ ) using the gallic acid calibration curve. Measurements were done in triplicate for each wine sample.

Determination of total flavonoid concentration. Total flavonoid concentration (TFC) of analysed red wine samples was determined using the colorimetric flavonoid determination method (Chun et al., 2003). Wine samples were diluted $1: 50$ with distilled water. $0.5 \mathrm{ml}$ of diluted wine solution was mixed with $2 \mathrm{ml}$ of distilled water and $0.15 \mathrm{ml}$ $5 \% \mathrm{NaNO}_{2}$. After 5 minutes, $0.15 \mathrm{ml} 10 \%$ anhydrous $\mathrm{AlCl}_{3}$ was added to the mixture. After another 5 minutes, $1 \mathrm{ml}$ of $1 \mathrm{M} \mathrm{NaOH}$ was added, mixed and kept in the dark at room temperature $\left(22 \pm 1{ }^{\circ} \mathrm{C}\right)$ for $15 \mathrm{~min}$. Absorbance was measured at wavelength $\lambda=415 \mathrm{~nm}$ using a UV-VIS JENWAY 6300 spectrophotometer (Baroworld Scientific Ltd, United Kingdom). Total flavonoid concentration of the analysed wine samples was expressed as miligrams of catechin equivalent per $100 \mathrm{ml}^{-1}$ of wine (CE mg per $100 \mathrm{ml}^{-1}$ ) using the catechin calibration curve. Measurements were done in triplicate for each wine sample.

Table 1. Characteristics of wine samples used in the study

\begin{tabular}{|c|c|c|c|c|c|c|}
\hline Wine ID code & Wine producer & Raw material & $\begin{array}{c}\text { Country } \\
\text { of production }\end{array}$ & $\begin{array}{c}\text { Alcohol content, } \\
\%\end{array}$ & $\begin{array}{c}\text { Year } \\
\text { of production }\end{array}$ & $\begin{array}{c}\text { Type } \\
\text { of packaging }\end{array}$ \\
\hline $\mathrm{AuCaS}$ & Jacobs Creek & $\begin{array}{l}\text { Cabernet Sauvignon } \\
\text { Shiraz }\end{array}$ & Australia & 13.9 & 2018 & Glass bottle \\
\hline FrMik & Lavel Blanc & $\begin{array}{l}\text { Blend of wines from European } \\
\text { Community countries }\end{array}$ & France & 11.0 & n.g. & Glass bottle \\
\hline FrCar & J.P. Chenet & $\begin{array}{l}\text { Carignan Shiraz } \\
\text { Merlot Grenache }\end{array}$ & France & 12.0 & n.g. & Glass bottle \\
\hline ItNdA & Barone Montalto & Nero d'Avola & Italy & 13.5 & n.g. & Glass bottle \\
\hline ItPri & Casa Charlize & Primitivo & Italy & 13.5 & n.g. & Glass bottle \\
\hline LvUp1 & Dadzis & Black currant & Latvia & 12.0 & 2019 & Glass bottle \\
\hline LvUp2 & Durbes Veltes & Black currant & Latvia & 12.0 & 2018 & Glass bottle \\
\hline LvUp3 & Abava Winery & Black currant & Latvia & 10.0 & n.g. & Glass bottle \\
\hline LvUp4 & Aizpute Winery & Black currant & Latvia & 12.0 & 2018 & Glass bottle \\
\hline LvAro & Zilver & Black chokeberry & Latvia & 12.0 & n.g. & Glass bottle \\
\hline SpCaS1 & Don Simon & Cabernet Sauvignon & Spain & 12.0 & n.g. & Tetra Pak \\
\hline SpMer & Don Simon & Merlot & Spain & 12.0 & n.g. & Tetra Pak \\
\hline SpCaS2 & El Matador Tinto Tetra & Cabernet Sauvignon & Spain & 11.0 & n.g. & Tetra Pak \\
\hline $\mathrm{ArCaS}$ & La Chamiza & Cabernet Sauvignon & Argentina & 13.0 & 2008 & Glass bottle \\
\hline SpTem & Valdepalacious & Tempranillo Grenache & Spain & 13.0 & 2006 & Glass bottle \\
\hline
\end{tabular}

*n.g. information is not given by the wine producers 
Determination of DPPH radical scavenging activity. Antiradical activity of the analysed wine samples was determined using 2,2-diphenyl-1-picrylhydrazyl-(DPPH) reagent (Haley et al., 2003). $0.5 \mathrm{ml}$ of wine solution was mixed with $3.5 \mathrm{ml}$ of DPPH methanol solution (0.004 g DPPH to $100 \mathrm{ml}$ methanol) and kept in the dark at room temperature $\left(22 \pm 1^{\circ} \mathrm{C}\right)$ for $30 \mathrm{~min}$. Absorbance was measured at wavelength $\lambda=517 \mathrm{~nm}$ using a UV-VIS JENWAY 6300 spectrophotometer (Baroworld Scientific Ltd, United Kingdom). Antiradical activity of the analysed wine samples was expressed as milimoles of Trolox equivalent of $100 \mathrm{ml}^{-1}$ of wine (TE mM $100 \mathrm{ml}^{-1}$ ) using the Trolox calibration curve. For each wine sample, three parallel dilutions with $1: 50$ distilled water were prepared and for each dilution three parallel measurements were repeated.

Determination of ABTS radical scavenging activity. Antiradical activity of the analysed wine samples was determined using the method for the determination of 2,2-azino-bis (3-ethylbenzthiazoline-6-sulfonic acid) (ABTS) radical cation (Pannala et al., 1999). Phosphate buffered saline (PBS) was obtained by dissolving $8.18 \mathrm{~g}$ $\mathrm{NaCl}, 0.27 \mathrm{~g} \mathrm{KH}_{2} \mathrm{PO}_{4}, 1.42 \mathrm{~g} \mathrm{Na}_{2} \mathrm{HPO}_{4}$ and $0.15 \mathrm{~g} \mathrm{KCl}$ in 11 of distilled water. For wine analysis, the ABTS solution was diluted with PBS to obtain the absorbance of $0.800 \pm$ 0.030 at wavelength $\lambda=734 \mathrm{~nm}$. For further analysis, $5 \mathrm{ml}$ ABTS solution was mixed with the diluted wine solution. Absorbance was measured at wavelength $\lambda=734 \mathrm{~nm}$ using a UV-VIS JENWAY 6300 spectrophotometer (Baroworld Scientific Ltd, United Kingdom). Antiradical activity of the analysed wine samples was expressed as milimoles of Trolox equivalent of $100 \mathrm{ml}^{-1}$ wine (TE mM $100 \mathrm{ml}^{-1}$ ) using the Trolox calibration curve. For each wine samples, three parallel dilutions with $1: 50$ distilled water were prepared and for each dilution, three parallel measurements were repeated.

Statistical analysis. Data mathematical processing was performed using statistical methods - arithmetic mean, standard deviation, and two-way analysis of variance (ANOVA) followed by Tukey's test using the software Microsoft Excel 2010. The analysis of hierarchical clusters, which can be used to classify data sets into subgroups or clusters, was performed using IBM SPSS Statistics version 17.0. For the interpretation of the results, it was assumed that $p=0.05$ with $95 \%$ confidence.

\section{RESULTS}

Total phenol concentration (TPC) in the analysed wine samples is shown in Figure 1. TPC concentration ranged from 109.08 \pm 10.17 GAE mg $\cdot 100 \mathrm{ml}^{-1}$ for sample FrMik (Lavel Blanc, France) to $348.66 \pm 5.13 \mathrm{GAE} \mathrm{mg} \cdot 100 \mathrm{ml}^{-1}$ for sample LvAro (Zilver, Latvia).

Total flavonoid concentration (TFC) in the analysed wine samples is shown in Figure 2. Total flavonoid concentration ranges from $95.42 \pm 8.22 \mathrm{CE} \mathrm{mg} \cdot 100 \mathrm{ml}^{-1}$ for sample LvUp4 (Aizpute Winery, Latvia) to $277.28 \pm 18.61 \mathrm{CE}$

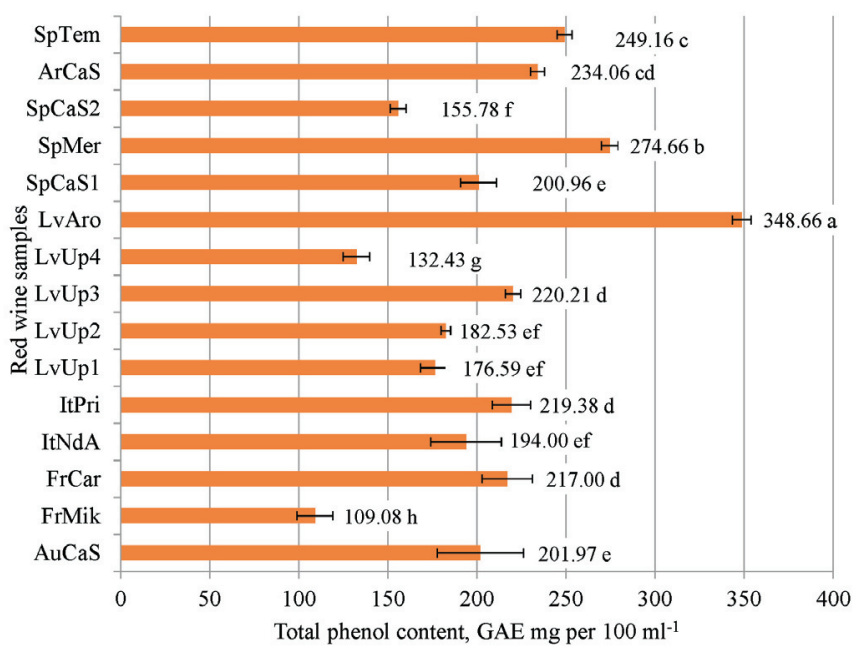

Fig. 1. Total phenol concentration in the analysed red wines samples.

AuCaS, Jacobs Creek; FrMik, Lavel Blanc; FrCar, J. P. Chenet; ItNdA, Barone Montalto; ItPri, Casa Charlize; LvUp1, Dadzis; LvUp2, Durbes Veltes; LvUp3, Abava Winery, LvUp4, Aizpute Winery; LvAro, Zilver; SpCaS1, Don Simon; SpMer, Don Simon; SpCaS2, El Matador Tinto Tetra; ArCaS, La Chamiza; SpTem, Valdepalacios

The same letters indicate that there not a significant difference between the values $(p>0.05)$.

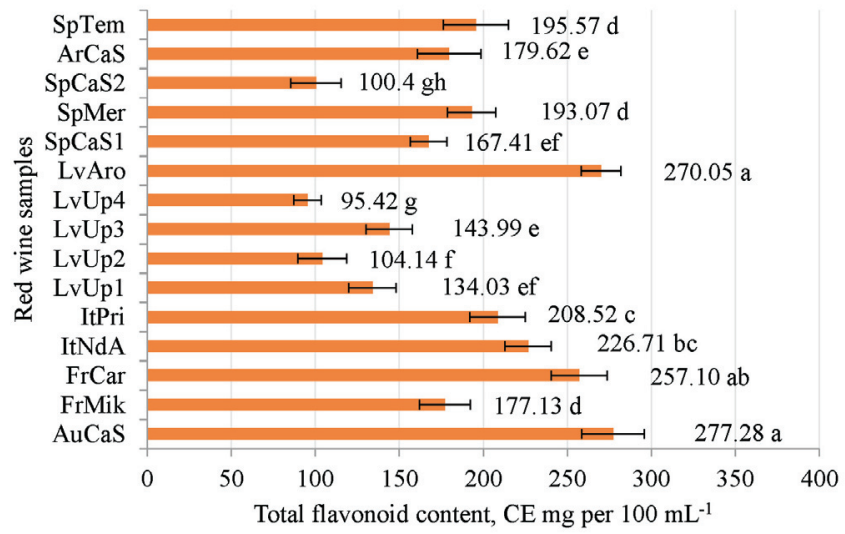

Fig. 2. Total flavonoid concentration in the analysed red wines samples.

AuCaS, Jacobs Creek; FrMik, Lavel Blanc; FrCar, J. P. Chenet; ItNdA, Barone Montalto; ItPri, Casa Charlize; LvUp1, Dadzis; LvUp2, Durbes Veltes; LvUp3, Abava Winery, LvUp4, Aizpute Winery; LvAro, Zilver; SpCaS1, Don Simon; SpMer, Don Simon; SpCaS2, El Matador Tinto Tetra; ArCaS, La Chamiza; SpTem, Valdepalacios.

The same letters indicate that there not a significant difference between the values $(p>0.05)$.

$\mathrm{mg} \cdot 100 \mathrm{ml}^{-1}, 270.05 \pm 11.91 \mathrm{CE} \mathrm{mg} \cdot 100 \mathrm{ml}^{-1}$ for samples AuCaS (Jacobs Creek, Australia) and LvAro (Zilver, Latvia), $p>0.05$.

Antiradical activity of the analysed wine samples was measured via DPPH and ABTS methods. The obtained antiradical activity data of the analysed wine samples is summarised in Table 2. Using the DPPH method, antiradical activity ranged from $9.61 \pm 0.05 \mathrm{TE} \mathrm{mM} \cdot 100 \mathrm{ml}^{-1}$ for sample LvUp4 (Aizpute Winery, Latvia) to $21.27 \pm 0.63 \mathrm{TE}$ $\mathrm{mM} \cdot 100 \mathrm{ml}^{-1}$ and $20.79 \pm 0.31 \mathrm{TE} \cdot 100 \mathrm{ml}^{-1}$ for samples LvAro (Zilver, Latvia) and ItPri (Casa Charlize, Italy). Us- 
Table 2. Antiradical activity of analysed red wines samples

\begin{tabular}{|c|c|c|}
\hline \multirow[t]{2}{*}{ Wine code } & \multicolumn{2}{|c|}{ Antiradical activity } \\
\hline & DPPH TE mM.100 $\mathrm{ml}^{-1}$ & ABTS TE $\mathrm{mM} \cdot 100 \mathrm{ml}^{-1}$ \\
\hline $\mathrm{AuCaS}$ & $19.29 \pm 0.25 \mathrm{c}$ & $33.95 \pm 1.81 \mathrm{~b}$ \\
\hline FrMik & $20.33 \pm 0.24 b$ & $29.66 \pm 1.22 \mathrm{c}$ \\
\hline FrCar & $19.63 \pm 0.06 \mathrm{bc}$ & $39.35 \pm 1.06 \mathrm{a}$ \\
\hline ItNdA & $18.77 \pm 0.11 \mathrm{~d}$ & $34.18 \pm 1.93 b$ \\
\hline ItPri & $20.79 \pm 0.31 a b$ & $42.96 \pm 1.09 \mathrm{a}$ \\
\hline LvUp1 & $11.21 \pm 0.25 \mathrm{~g}$ & $28.98 \pm 1.54 \mathrm{c}$ \\
\hline LvUp2 & $16.83 \pm 0.28 \mathrm{e}$ & $30.06 \pm 1.47 \mathrm{bc}$ \\
\hline LvUp3 & $13.51 \pm 0.11 \mathrm{f}$ & $32.76 \pm 2.67 \mathrm{~b}$ \\
\hline LvUp4 & $9.61 \pm 0.05 h$ & $25.69 \pm 0.96 \mathrm{~d}$ \\
\hline LvAro & $21.27 \pm 0.63 \mathrm{a}$ & $12.15 \pm 0.83 \mathrm{e}$ \\
\hline SpCaS1 & $16.99 \pm 0.49 \mathrm{e}$ & $6.79 \pm 0.93 \mathrm{f}$ \\
\hline SpMer & $19.22 \pm 0.30 \mathrm{c}$ & $7.61 \pm 1.54 \mathrm{f}$ \\
\hline $\mathrm{SpCaS} 2$ & $14.36 \pm 0.34 \mathrm{f}$ & $12.15 \pm 1.08 \mathrm{e}$ \\
\hline $\mathrm{ArCaS}$ & $18.04 \pm 0.35 \mathrm{~d}$ & $8.02 \pm 0.69 f$ \\
\hline SpTem & $19.08 \pm 0.24 \mathrm{c}$ & $10.74 \pm 0.86 \mathrm{e}$ \\
\hline
\end{tabular}

AuCaS, Jacobs Creek; FrMik, Lavel Blanc; FrCar, J. P. Chenet; ItNdA, Barone Montalto; ItPri, Casa Charlize; LvUp1, Dadzis; LvUp2, Durbes Veltes; LvUp3, Abava Winery, LvUp4, Aizpute Winery; LvAro, Zilver; SpCaS1, Don Simon; SpMer, Don Simon; SpCaS2, El Matador Tinto Tetra; ArCaS, La Chamiza; SpTem, Valdepalacios

The highest and lowest antiradical activity values via both DPPH and ABTS methods are highlighted in bold. The same letters indicate that there not a significant difference between the values $(p>0.05)$.

ing the ABTS method, samples ItPri (Casa Charlize, Italy) and FrCar (J.P. Chenet France) showed the highest antiradical activity $-42.96 \pm 1.09 \mathrm{TE} \mathrm{mM} \cdot 100 \mathrm{ml}^{-1}, 39.35 \pm 1.06$ TE mM.100 $\mathrm{ml}^{-1}$, while samples SpCaS1 (Don Simon, Spain), SpMer (Don Simon, Spain) and ArCaS (La Chamiza, Argentina) show the lowest antiradical activity, i.e., $6.79 \pm 1.93 \mathrm{TE} \mathrm{mM} \cdot 100 \mathrm{ml}^{-1}, 7.61 \pm 1.54 \mathrm{TE} \mathrm{mM} \cdot 100$ $\mathrm{ml}^{-1}$ and $8.02 \pm 0.69 \mathrm{TE} \mathrm{mM} \cdot 100 \mathrm{ml}^{-1}, p>0.05$.

Cluster analysis (see Figure 3) divided the red wine samples into five clusters according to the concentration of total phenols, flavonoids, and antiradical activity.

Cluster 1 included red wine with high TPC (348.66 \pm 5.13 GAE mg.100 ml $\left.{ }^{-1}\right)$ and TFC (270.05 $\pm 11.91 \mathrm{CE} \mathrm{mg} \cdot 100$ $\left.\mathrm{ml}^{-1}\right)$, high antiradical activity via DPPH method $(21.27 \pm$ $\left.0.63 \mathrm{TE} \mathrm{mM} \cdot 100 \mathrm{ml}^{-1}\right)$, and relatively low antiradical activity via ABTS method $\left(12.15 \pm 0.83 \mathrm{TE} \mathrm{mM} \cdot 100 \mathrm{ml}^{-1}\right)-$ sample LvAro.

Cluster 2 contained red wines with low TPC (109.08 \pm 10.17 GAE mg. $\left.100 \mathrm{ml}^{-1}\right)$, average TFC $(177.13 \pm 15.25 \mathrm{CE}$ $\mathrm{mg} .100 \mathrm{ml}^{-1}$ ) and average antiradical activity via both DPPH $\left(20.33 \pm 0.24 \mathrm{TE} \mathrm{mM} \cdot 100 \mathrm{ml}^{-1}\right)$, and ABTS (29.66 \pm $1.22 \mathrm{TE} \mathrm{mM} \cdot 100 \mathrm{ml}^{-1}$ ) methods — sample FrMik.

Cluster 3 combined red wines with low TPC ranging from $132.43 \pm 7.51$ to $182.53 \pm 2.70 \mathrm{GAE} \mathrm{mg} \cdot 100 \mathrm{ml}^{-1}$, low TFC ranging from $95.42 \pm 8.22$ to 134.03 to $14.01 \mathrm{CE} \mathrm{mg} \cdot 100$ $\mathrm{ml}^{-1}$, low antiradical activity via DPPH method ranging from $9.61 \pm 0.05$ to $16.83 \pm 0.28 \mathrm{TE} \mathrm{mM} \cdot 100 \mathrm{ml}^{-1}$ and me-

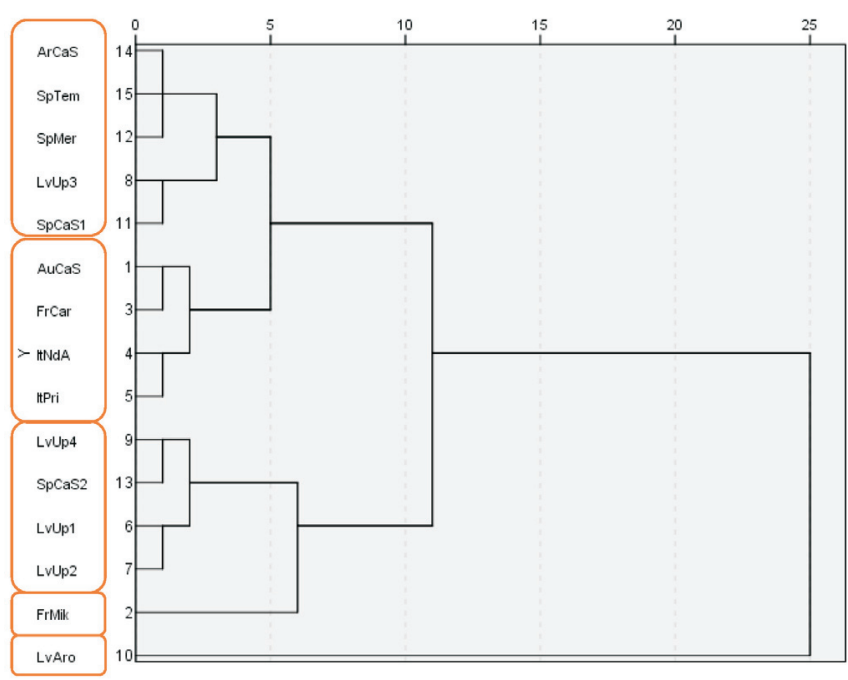

Fig. 3. Analysis of clusters of TPC, TFC and antiradical activity.

AuCaS, Jacobs Creek; FrMik, Lavel Blanc; FrCar, J. P. Chenet; ItNdA, Barone Montalto; ItPri, Casa Charlize; LvUp1, Dadzis; LvUp2, Durbes Veltes; LvUp3, Abava Winery, LvUp4, Aizpute Winery; LvAro, Zilver; SpCaS1, Don Simon; SpMer, Don Simon; SpCaS2, El Matador Tinto Tetra; ArCaS, La Chamiza; SpTem, Valdepalacios.

dium antiradical activity via ABTS method ranging from $12.15 \pm 1.08$ to $30.06 \pm 1.47 \mathrm{TE} \mathrm{mM} \cdot 100 \mathrm{ml}^{-1}$ (samples LvUp1, LvUp2, LvUp4, and SpCaS2).

Cluster 4 included red wines with medium TPC ranging from $194.00 \pm 9.77$ to $219.38 \pm 10.71 \mathrm{GAE} \mathrm{mg} \cdot 100 \mathrm{ml}^{-1}$, high TFC ranging from $208.52 \pm 16.44$ to $277.28 \pm 18.61$ $\mathrm{CE} \mathrm{mg} \cdot 100 \mathrm{ml}^{-1}$ and high antiradical activity via DPPH method ranging from $18.77 \pm 0.11$ to $20.79 \pm 0.31 \mathrm{TE}$ $\mathrm{mM} \cdot 100 \mathrm{ml}^{-1}$ and ABTS method ranging from $33.95 \pm 1.81$ to $42.96 \pm 1.09 \mathrm{TE} \mathrm{mM} \cdot 100 \mathrm{ml}^{-1}$ (samples AuCaS, FrCar, ItNdA, ItPri).

Cluster 5 contained red wines with high TPC (200.96 \pm $\left.10.11-274.66 \pm 4.77 \mathrm{GAE} \mathrm{mg} \cdot 100 \mathrm{ml}^{-1}\right)$, medium TFC $\left(143.99 \pm 13.87-195.57 \pm 19.35 \mathrm{CE} \mathrm{mg} \cdot 100 \mathrm{ml}^{-1}\right)$, and medium antiradical activity via both DPPH $(13.51 \pm 0.11-$ $\left.19.22 \pm 0.30 \mathrm{TE} \mathrm{mM} \cdot 100 \mathrm{ml}^{-1}\right)$ and ABTS $(6.79 \pm 0.93-$ $32.76 \pm 2.67 \mathrm{TE} \mathrm{mM} \cdot 100 \mathrm{ml}^{-1}$ ) methods (samples ArCaS, SpTem, SpMer, SpCaS1, and LvUp3).

\section{DISCUSSION}

The highest TPC among analysed red wine samples was found in the Latvian chokeberry wine sample LvAro (Zil-

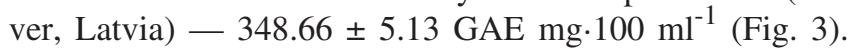
This level is higher than determined in the studies of other authors. Čakar et al. (2016) concluded that, depending on production technology used, total phenol concentration in chokeberry wines can range from $233.09 \pm 1.25$ GAE $\mathrm{mg} \cdot 100 \mathrm{ml}^{-1}$ to $241.46 \pm 0.98 \mathrm{GAE} \mathrm{mg} \cdot 100 \mathrm{ml}^{-1}$, whereas Czarnecki et al. (2011) concluded that TPC in chokeberry wine is $319.89 \pm 21.69 \mathrm{GAE} \mathrm{mg} \cdot 100 \mathrm{ml}^{-1}$. These studies also concluded that chokeberry wine contains the highest concentrations of most phenolic compounds among ana- 
lysed berry (raspberry, white and red grape, blackberry, blueberry, chokeberry, sour cherry) and fruit (apple) wines, which are in line with the results of this study. The lowest concentration of TPC $\left(109.08 \pm 10.17 \mathrm{GAE} \mathrm{mg} \cdot 100 \mathrm{ml}^{-1}\right)$ was found in the sample FrMik (Lavel Blanc, France) prepared from wines from unknown raw material from European Community countries. Latvian berry (blackcurrant and black chokeberry) wines are produced in private wineries in Durbe (Dadzis and Durbes veltes - black currant wines), Aizpute (Aizpute winery black currant wine), Sigulda region (Zilver — black chokeberry wine) and Tukums region (Abava winery - black currant wine). The Latvian berry wines are made from berry juice, sugar, and water. In order to ensure the expressiveness of the taste of berry wines, only ripe and high-quality raw materials are used in the production. No dyes, preservatives, flavourings or other fruit and berry additives are added to the wines during the production process. Wines contain sulphites naturally occurring during fermentation. To produce black currant wines, Latvian winemakers choose blackcurrant varieties 'Titania' and 'Zagadka', because they are productive, suitable for processing with a pronounced sweet and sour taste, and are resistant to various plant diseases. The chokeberry wine analysed in the study was made from black chokeberry (Aronia melanocarpa). The obtained results showed that the wines from black currant compared with red grape wines do not have a high concentration of biologically active compounds. Relatively low TPC $\left(132.43 \pm 7.51 \mathrm{GAE} \mathrm{mg} \cdot 100 \mathrm{ml}^{-1}\right)$ was also found in the black currant wine sample LvUp4 (Aizpute winery, Latvia). Previous studies found that phenolic compound concentration in black currant wine was 201.36 GAE mg.100 ml ${ }^{-1}$ (Curko et al., 2016) and 145.75-150.90 GAE mg.100 ml-1 (Ekholm et al., 2013; Punbusayakul, 2018). This means that the obtained results for the sample LvUp4 are 1.1 to 1.5 times lower than in the studies mentioned above. The other analysed black currant wine samples showed higher total phenol concentration. The observed differences in total phenols can be explained by possible differences in berry variety, year of harvest, climate conditions, environmental factors, degree of ripeness of berries at harvest, oenological practises used and storage conditions (Chankvetadze et al., 2018).

The highest total flavonoid concentration was found for samples AuCaS (Jacobs Creek, Australia) and LvAro

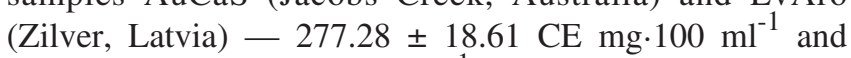
$270.05 \pm 11.91 \mathrm{CE} \mathrm{mg} \cdot 100 \mathrm{ml}^{-1}$, respectively (Fig. 2), $p>$ 0.05. Sample AuCaS was made from Cabernet Sauvignon and Shiraz grapes with a high concentration of flavonoids. Flavonoid compound concentration of Cabernet Sauvignon wine may range between $85.99 \pm 5.55 \mathrm{CE} \mathrm{mg} \cdot 100 \mathrm{ml}^{-1}$ to $229.03 \pm 15.72 \mathrm{CE} \mathrm{mg} \cdot 100 \mathrm{ml}^{-1}$ (Jiang and Zhang, 2012) and for Shiraz grape wines $-94.12 \pm 8.76-114.02 \pm 3.50$ CE mg. $100 \mathrm{ml}^{-1}$ (Escudero-Gilete et al., 2016). The concentration of total flavonoids in the AuCaS sample obtained in the study is higher than in the studies of the mentioned authors, which is likely because AuCaS is a mixed wine. Sample LvAro was obtained from chokeberries, which contain total flavonoids at concentration $219.30 \pm 8.60 \mathrm{CE} \mathrm{mg} \cdot 100$ $\mathrm{ml}^{-1}$ to $438.40 \pm 51.70 \mathrm{CE} \mathrm{mg} \cdot 100 \mathrm{ml}^{-1}$, depending on the variety (Jurčevic et al., 2015). This agrees with the observed concentration in LvAro wine $(270.05 \pm 11.91 \mathrm{CE}$ $\mathrm{mg} \cdot 100 \mathrm{ml}^{-1}$ ). The lowest concentration of total flavonoids was found for sample LvUp4 (Aizpute Winery, Latvia) $95.42 \pm 8.22 \mathrm{CE} \mathrm{mg} \cdot 100 \mathrm{ml}^{-1}$. A similar total flavonoid concentration $(88.90 \pm 1.63$ to $97.51 \pm 1.29 \mathrm{CE} \mathrm{mg \cdot 100}$ $\mathrm{ml}^{-1}$ ) in blackcurrant wine was observed by Kostic et al. (2011), while Ayvaz et al. (2015) found that black currant wine may contain up to $142.52 \mathrm{CE} \mathrm{mg} \cdot 100 \mathrm{ml}^{-1}$. The other black currant wines studied (LvUp1, LvUp2, LvUp3, $p<$ $0.05)$ contained a higher concentration of total flavonoids than sample LvUp4, which agrees with the results of Aywaz et al. (2015). The observed differences in total flavonoid concentration can also be explained by possible differences in berry variety, year of harvest, climate conditions, environmental factors, degree of ripeness of berries at harvest, oenological practises used, and storage conditions (Chankvetadze et al., 2018).

The highest antiradical activity via DPPH method was found for samples LvAro (Zilver, Latvia) and ItPri (Casa Charlize, Italy) $-21.27 \pm 0.63 \mathrm{TE} \mathrm{mM} \cdot 100 \mathrm{ml}^{-1}$ and 20.79 $\pm 0.31 \mathrm{TE} \mathrm{mM} \cdot 100 \mathrm{ml}^{-1}$, respectively (Table 2 ). The obtained results are in agreement with previous studies on chokecherry wine and other products: from $12.09 \pm 0.93$ to $40.19 \pm 2.13 \mathrm{TE} \mathrm{mM} \cdot 100 \mathrm{ml}^{-1}$ (Jurčevic et al., 2015; Jakobek et al., 2007). The lowest antiradical activity via DPPH method was found for the sample LvUp4 (Aizpute Winery, Latvia) - 9.61 $\pm 0.05 \mathrm{TE} \mathrm{mM} \cdot 100 \mathrm{ml}^{-1}$, while the other black currant wines had even higher antiradical activity ranging from $11.21 \pm 0.25$ to $16.83 \pm 0.28 \mathrm{TE} \mathrm{mM} \cdot 100$ $\mathrm{ml}^{-1}$, which is significantly higher than that of the black currant wine analysed in another study (Punbusayakul, 2018) $-6.91 \pm 0.46 \mathrm{TE} \mathrm{mM} \cdot 100 \mathrm{ml}^{-1}$. The differences between the results can be explained by differences in climatic conditions, oenological practices, or blackcurrant varieties (Chankvetadze et al., 2018).

In contrast, the highest antiradical activity via ABTS method was found for samples ItPri (Casa Charlize, Italy) and FrCar (J. P. Chenet, France) - $42.96 \pm 1.09$ TE $\mathrm{mM} \cdot 100 \mathrm{ml}^{-1}$ and $39.35 \pm 1.06 \mathrm{TE} \mathrm{mM} \cdot 100 \mathrm{ml}^{-1}$, respectively. The obtained results agree with previous studies (Faccia et al., 2016; Carluccio et al., 2019) studies on Primitivo wine using the same method: up to $64.60 \pm 1.10$ TE $\mathrm{mM} \cdot 100 \mathrm{ml}^{-1}$ depending on the oenological practises used. The lowest antiradical activity via ABTS method was found for samples SpCaS1 (Don Simon, Spain), SpMer (Don Simon, Spain) and ArCaS (La Chamiza, Argentina) $-6.79 \pm 1.93 \mathrm{TE} \mathrm{mM} \cdot 100 \mathrm{ml}^{-1}, 7.61 \pm 1.54 \mathrm{TE} \mathrm{mM} \cdot 100$ $\mathrm{ml}^{-1}$ and $8.02 \pm 0.69 \mathrm{TE} \mathrm{mM} \cdot 100 \mathrm{ml}^{-1}$, respectively. De Beer et al. (2003) and Carranza-Concha et al. (2017) also concluded that Cabernet and Merlot wines have low antiradical activity (via ABTS method) -10.90 to 13.18 $\mathrm{mM}$ TE. $100 \mathrm{ml}^{-1}$. The low antiradical activity of ArCaS can be explained by wine aging, which contributed to the reduction of polyphenolic compounds in wine, as it was produced in 2008 . 


\section{CONCLUSIONS}

The results indicated that the analysed red grape and berry wines available for purchase in Latvia differ in the composition of bioactive compounds. The cluster analyses showed that black chokeberry wine (LvAro) was separated from the rest, and it has high TPC, TFC, and DPPH activity. Red grape wines from different origins as Australia (AuCaS), France (FrCar), and Italy (ItNdA, ItPri) were also separated in a cluster characteristic with high TFC and antioxidant activity.

\section{REFERENCES}

Ayvaz, H., Diaconeasa, Z., Leopold, L., Rugina, D., Socaciu, C. (2015). Antiproliferative and antioxidant properties of anthocyanin rich extracts from blueberry and blackcurrant juice. Int. J. Mol. Sci., 16 (2), 2352-2365.

Bodnieks, E., Neimane, L., Zariņ̌̌, Z. (2015). Uztura mācība [Nutrition Science]. LU Akadēmiskais Apgāds, Rīga. 432 lpp. (in Latvian).

Bonello, F., Cassino, C., Cravero, M. C., Gianotti, V., Osella, D., Tsolakis, C. (2016). Antioxidant composition of a selection of Italian red wines and their corresponding free-radical scavenging activity. J. Chem., 2016 (3), $1-8$.

Čakar, U. D., Dordevic, B. I., Milovanovic, M. M., Petrovic, A. V., Vajs, V. E., Zevarik, J., Zivkovic, M. B. (2016). Phenolic profile of some fruit wines and their antioxidant properties. Hem. Ind., 70 (6), 661-672.

Carluccio, M. A., Giovinazzo, G., Grieco, F. (2019). Autochthonous Saccharomyces cerevisiae starter cultures enhance polyphenols content, antioxidant activity, and anti-inflammatory response of Apulian red wines. Foods, 8 (453), 1-14.

Carranza-Concha, J., Carranza-Tellez, J., Contreras-Martinez, C. S., Franco-Banuelus, A. (2017). Total phenolic content and antioxidant capacity of wine grapes grown in Zacatecas, Mexico. Agrociencia, 51 (6), 661-671.

Chamizo-Gonzalez, F., Gonzalez- Miret, L. M., Gordillio, B., Heredia, J. F. (2020). Impact of alternative protein fining agents on the phenolic composition and color of Shyrah red wines from warm climate. Food Chem., 342 (2), 128297.

Chankvetadze, B., Chankvetadze, L., Ebelashvili, N., Japaridze, M., Kekelidze, I., (2018). Phenolic antioxidants in red dessert wine produced with innovative technology. Ann. of Agrar. Sci., 16 (1), 34-38.

Chun, O. K., Kim, D. O., Kim, Y. J., Lee, C. Y., Moon, H. Y. (2003). Quantification of polyphenolics and their antioxidant capacity in fresh plums. $J$. Agric. Food Chem., 51 (22), 6509-6515.

Corder, R., Dhariwal, S. K., Husain, F., Kang, S. S., Khan, N. Q., Patel, B., Pothecary, M. R., Wood, E. G. (2015). Regulation of vascular endothelial function by red wine procyanidins: implications for cardiovascular health. Tetrahedron, 71 (20), 3059-3065.

Cortez, R. E., Gonzalez de Mejia, E. (2019). Black currants (Ribes nigrum): A review on chemistry, processing, and health benefits. J. Food Sci., 84 (9), 2387-2401.

Curko, N., Gaurina, Srček, V., Ljevar, A., Kovačevic Ganic, K., Radoševic, K., Tomaševic, M. (2016). Phenolic composition, antioxidant capacity and in vitro cytotoxicity assessment of fruit wines. Food Technol. Biotechnol., 54 (2), 145-155.
Czarnecki, Z., Gumienna, M., Lasik, M. (2011). Bioconversion of grape and chokeberry wine polyphenols during simulated gastrointestinal in vitro digestion. J. Food Sci. Nutr., 62 (3), 226-233.

De Beer, D., Gelderblom, W. C., Joubert, E., Manley, M. (2003). Antioxidant activity of South African red and white cultivar wines: Free radical scavenging. J. Agric. Food Chem., 51 (4), 902-909.

Ekholm, A., Flick, G., Paschke, M., Rajeev, Vagiri, M., Rumpunen, K. (2013). Blackcurrant wine and vinegar: Effects of processing methods on content of beneficial polyphenols - a pilot study. Swedish University of Agricultural Sciences. http://archive.northsearegion.eu/files/repository/ 20140106104028_2013-SE-Enclosure11.pdf (accessed 15.12.2021).

Escudero-Gilete, M. L., Heredia, F. J., Hernanz, D., Jara- Palacios, M. J. (2016). The use of grape seed byproducts rich in flavonoids to improve the antioxidant potential of red wines. Molecules, 21 (11), 1-12.

Faccia, M., Gambacorta, G., Punzi, R., Trani, A., Verrastro, V. (2016). Phenols, volatiles and sensory properties of primitivo wines from the "Gioia Del Colle” PDO area. S. Afr. J. Enol., 37 (2), 139-148.

Garavaglia, J., Marcadenti, A., Markoski, M. M., Olivaes, J., Oliveira, A. (2016). Molecular properties of red wine compounds and cardiometabolic benefits. Nutr. Metab. Insights, 9, 51-57.

Giri, B., Pandeya, A., Pokhrel, P., Rayamajhi, S. (2018). Evaluation of secondary metabolites, antioxidant activity and color parameters of Nepali wines. Nutr. Food Sci., 6 (8), 2252-2263.

Haley, S., Harris, M., Perret, J., Wilson, J., Ju, L. (2003). Antioxidant properties of bran extracts from "Akron" wheat grown at different locations. $J$. Agric. Food Chem., 51 (6), 1566-1570.

Jakobek, L., Medvidovic-Kosanovic, M., Novak, Jovanovic, I., Šeruga, M. (2007). Antioxidant activity and polyphenols of aronia in comparison to other berry species. Agric. Conspec. Sci, 72 (4), 301-306.

Jiang, B., Zhang, Z. W. (2012). Comparison of phenolic compounds and antioxidant properties of cabernet sauvignon and merlot wines from four wine grape-growing regions in China. Molecules, 17 (8), 8804-8821.

Jurčevic, I. L., Krbavčic, I. P., Markovic, K., Tolic, M. T., Vahčic, N. (2015). Phenolic content, antioxidant capacity and quality of chokeberry (Aronia melanocarpa) products. Food Technol. Biotechnol, 53 (2), 171-179.

Kostic, D. A., Micic, R. J., Mitic, M. N., Naskovic, D. Č., Obradovic, M. V. (2011). Phenolics content and antioxidant capacity of commercial red fruit juices. Hem. Ind., 65 (5), 611-619.

Lamuela-Raventos, R. M., Orthofer, R., Singleton, V. R. (1999). Analysis of total phenols and other oxidation substrates and antioxidants by means of Folin-Ciocalteu reagent. Meth. Enzymol, 299, 152-178.

Legzdina, Z., Straumite, E. (2020). Wine buying habits of Latvian consumers. In: $15^{\text {th }}$ International Scientific Conference "Students on Their Way to Science” (Undergraduate, Graduate, Post-graduate Students, Jelgava, Latvia, 24 April 2020: Collection of Abstracts, 46.

https://1lufb.11u.1v/conference/Students_their_Way_Science/ Latvia_SWS_15th_Collection_of_Abstracts_2020.pdf (accessed 10.01.2022)..

Pannala, A., Pellegrini, N., Proteggente, A., Re, R., Rice-Evans, C., Yang, M. (1999). Antioxidant activity applying an improved ABTS radical cation decolorization assay. Free Radic Biol. Med., 26 (9-10), 1231-1237.

Punbusayakul, N. (2018). Bioactive compounds and antioxidant activity of wines from different currant cultivars. J. Process. Energy Agricult., 22 (1), 27-30.

Sidor, A., Gramza-Michalowska, A. (2019). Black chokeberry Aronia Melanocarpa L.: Aqualitative composition, phenolic profile and antioxidant potential. Molecules, 24 (20), 3710. 


\section{BIOLOĢISKI AKTĪVO VIELU ANALĪZE LATVIJĀ NOPĒRKAMOS SARKANVĪNOS}

Vīns ir viens no pasaulē biežāk lietotajiem alkoholiskajiem dzērieniem. Kaut arī pārmērīga alkoholisko dzērienu lietošana var izraisīt nopietnas veselības problēmas, ir secināts, ka vīna mērena lietošana var veselību uzlabot. Vīna pozitīvā ietekme uz veselību tiek pamatota ar tā sastāvā esošo antioksidantu — polifenolu savienojumu — darbību. Sarkanvīns satur vairāk polifenolu savienojumu nekā baltvīns, tāpēc to uzskata par veselīgāku. Pētījuma mērkis bija analizēt Latvijā nopērkamo sarkanvīnu kopējo fenolu, kopējo flavonoīdu saturu un antiradikālo aktivitāti. Pētījumā analizēti 15 Latvijas lielveikalos iegādājami vīnogu un ogu sarkanvīni. Kopējais fenolu saturs noteikts, izmantojot Folin-Ciocalteu spektrofotometrisko metodi ar nelielām izmain̄ām. Kopējais flavonoīdu saturs noteikts, izmantojot kolorimetrisko flavonoīdu noteikšanas metodi. Antiradikālā aktivitāte noteikta, izmantojot DPPH reaǵentu un ABTS radikāḷu katjonu noteikšanas metodi. Iegūtie rezultāti rāda, ka visus analizētos sarkanvīnu paraugus pēc kopējo fenolu un kopējo flavonoīdu satura un antiradikālās aktivitātes var iedalīt piecos klasteros. 1. klasterī atsevišķi izdalīts paraugs LvAro, tas ir, Latvijas aroniju vīns, ar augstu kopējo fenolu un kopējo flavonoīdu saturu un antiradikālo aktivitāti, noteiktu ar DPPH metodi, bet salīdzinoši zemu antiradikālo aktivitāti, nosakot ar ABTS metodi. 4. klasteris apvieno dažādu valstu vīnogu vīnus ar vidēju kopējo fenolu saturu, augstu kopējo flavonoīdu saturu un augstu antiradikālo aktivitāti, noteiktu gan ar DPPH, gan ABTS metodi (paraugi AuCaS, FrCar, ItndA, ItPri). 5. klasteris apvieno sarkanvīnus ar augstu kopējo fenolu un vidēju kopējo flavonoīdu saturu, vidēju antiradikālo aktivitāti, noteiktu gan ar DPPH, gan ABTS metodi (paraugi ArCaS, SpTem, SpMer, SpCaS1, LvUp3). 